\title{
Beta-globin gene mutations in children with beta-thalassemia major from Şanlıurfa province, Turkey
}

Türkiye, Sanlurfa bölgesinde talasemi majorlü çocuk hastalarda beta-globin gen mutasyonlart

\author{
Ali Ayçiçek ${ }^{1}$, Ahmet Koç${ }^{1}$, Zeynep Canan Özdemir ${ }^{1}$, Hasan Bilinç², \\ Abdurrahim Koçyiğit ${ }^{2}$, Fuat Dilmeç3 \\ 1Department of Pediatric Hematology, Faculty of Medicine, Harran University, Sanlurfa, Turkey \\ ${ }^{2}$ Department of Biochemistry, Faculty of Medicine, Harran University, Şanlurfa, Turkey \\ ${ }^{3}$ Department of Medical Biology, Faculty of Medicine, Harran University, Şanlurfa, Turkey
}

\begin{abstract}
Objective: The prevalence of $\beta$-thalassemia in Şanlurfa province, Turkey is reported to be 2.6\%-3.7\%, whereas nation-wide the frequency of $\beta$-thalassemia is $2 \%$. This study aimed to identify the most frequent $\beta$-thalassemia mutations in Şanliurfa province.

Materials and Methods: In total, 22 mutations were investigated in 115 pediatric patients with $\beta$-thalassemia using a commercially available reverse dot blot platform.

Results: The study included 60 male and 55 female patients with a mean age of 7.3 44.6 years (range: 1-17 years). In total, $76 \%$ of the patients had consanguineous parents. In all, 16 different mutations were observed in the 115 patients. IVS-1-110 (G-A) (29.1\%), IVS-1-1 (G-A) (13.9\%), codon 39 (C>T) (10.4\%), and codon 8 (-AA) (9.1\%) accounted for $62.5 \%$ of all the $\beta$-thalassemia mutations, and $6 \%$ of the patients had 2 different thalassemia mutations. According to the present results, IVS-1-110 (G>A) was the most frequent mutation observed in the patients from Şanluurfa province, as in other geographical regions of Turkey. In addition, the following 34 compound heterozygote mutant alleles were observed; IVS-1-1 (G>A)/IVS $2.848(\mathrm{n}=4)$, codon $39(\mathrm{C}>\mathrm{T}) /$ codon $8(-\mathrm{AA})(\mathrm{n}=2)$, codon $6(-\mathrm{A}) / \mathrm{IVS}$ $1.5(\mathrm{G}>\mathrm{C})(\mathrm{n}=2)$, IVS-1-110 (G>A)/IVS-1-1 $(\mathrm{G}>\mathrm{A})(\mathrm{n}=2)$, IVS-1-110 (G>A)/codon $8(-\mathrm{AA})(\mathrm{n}=1)$, IVS-1-110 (G>A)/codon 39 (C>T) $(n=1)$, IVS-1-110 (G>A)/IVS-1-6 $(\mathrm{T}>\mathrm{C})(\mathrm{n}=1)$, IVS-1-110 $(\mathrm{G}>\mathrm{A}) /$ IVS-1-5 (G>C) $(n=1)$, IVS-1-110 $(G>A] /$ codon 8/9 $(+G)(n=1)$, IVS-1-1 $(G>A) /$ codon $39(C>T)$ $(n=1)$, and codon $8(-A A) / I V S-1-5(G>C)(n=1)$. The following $\beta$-globin gene promoter mutations were not observed; -101 (C>T), -87(C>T), -30 (T>A), codon $15(\mathrm{TTG}>\mathrm{TGA})$, codon $27(\mathrm{G}>\mathrm{T}) \mathrm{Knossos}$, and IVS-1-116 $(\mathrm{G}>\mathrm{C})$. In all, 5 of the 115 patients $(4.3 \%)$ had an unidentified mutation.

Conclusion: The present results illustrate the heterogeneity of $\beta$-thalassemia mutations in Şanliurfa Province. The present findings may be of value for genetic counseling, and premarital and prenatal diagnosis in Şanlıurfa province. (Turk J Hematol 2011; 28: 264-8)

Key words: Beta-thalassemia, mutation, Şanlıurfa, Turkey
\end{abstract}

Received: January 12, 2011

Accepted: July 12, 2011

Address for Correspondence: Assoc. Prof. Ali Ayçiçek, Department of Pediatric Hematology, Faculty of Medicine, Harran University, Şanlıurfa, Turkey Phone: +90 4143183000 E-mail: ayciceka@hotmail.com 


\section{Özet}

Amaç: Türkiye genelinde \%2 olan beta-talasemi sıklığı Türkiye'nin güneydoğu bölgesinde yer alan Şanlıurfa ilinde \%2.6-\%3.7 arasında olduğu bulunmuştur. Bu çalışmada en sık gözlenen mutasyon tiplerini arastırdık.

Yöntem ve Gereçler: Bu çalışmada beta talasemili 115 çocuk hastada 22 adet mutasyon ticari ters dot blot seritler ile araştırıld.

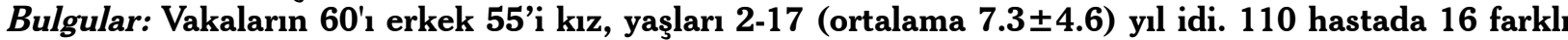
mutasyon saptand. IVS-1-110 (G-A) \%29.1, IVS-1-1 (G-A) \%13.9, codon 39 (C>T) \%10.4, codon 8 (-AA) \%9.1 en sık olarak belirlendi ve bunların vakaların \%62.5'ini oluşturduğu görüldü. Türkiye'nin diğer bölgelerinde olduğu gibi IVI-1-110 (G>A) en sık saptanan mutasyon olmuştur. Çalışmada IVS1-1 (G>A)/IVS 2.848 (4 vaka), codon 39 (C>T)/codon 8 (-AA) (2), codon 6 (-A)/IVS-1-5 (G>C) (2), IVS-1-110 (G>A)/IVS-1-1 (G>A) (2), IVS-1-110 (G>A)/codon 8 (-AA) (1), IVS-1-110 (G >A)/codon 39 (C>T) (1), IVS-1-110 (G>A)/IVS-1-6 (T>C) (1), IVS-1-110 (G>A)/IVS-1-5 (G>C) (1), IVS-1-110 $(G>A) /$ codon 8/9 (+G) (1), IVS-1-1 (G>A)/codon $39(C>T)(1)$, codon $8(-A A) / I V S-1-5(G>C)(1)$ adet olmak üzere 34 mutant alelin birleşik heterozigot mutasyon oluşturduğu saptandı. $-101(C>T)$, $-87(\mathrm{C}>\mathrm{T}),-30(\mathrm{~T}>\mathrm{A})$, codon 15 (TTG $>$ TGA), codon $27(\mathrm{G}>\mathrm{T})$ Knossos ve IVS-1-116 $(\mathrm{T}>\mathrm{G})$ $\beta$-globin geni promoter bölgesi mutasyonları hiç bir hastada tesbit edilmedi. 5 (\%4.3) hastanın mutasyonu saptanamadi.

Sonuç: Şanlıurfa bölgesinde $\beta$-talasemi çok çeşitli mutasyonlarla ortaya çıkmaktadır. Bu sonuçlar genetik danışma ve doğum öncesi tanıda yardımcı olabilir. (Turk J Hematol 2011; 28: 271-5)

Anahtar kelimeler: Beta-talasemi, mutasyon, Şanlıurfa, Türkiye

Kabul tarihi: 12 Temmuz 2011

\section{Introduction}

Although $\beta$-thalassemia is associated with $>200$ mutations, most are rare [1]. Approximately 20 common alleles constitute $80 \%$ of all known thalassemias worldwide; $3 \%$ of the world's population carries genes for $\beta$-thalassemia. The overall frequency of $\beta$-thalassemia in Turkey is $2 \%$, but within the country the rate differs significantly according to region. In particular areas of the country there are fewer common alleles. The highest frequencies of $\beta$-thalassemia in Turkey are observed in Antalya, Thrace (10\% each), and Muğla (4.8\%) [2]. The frequency of $\beta$-thalassemia in Turkey is lowest in eastern and northern Anatolia, and is moderate in southern Anatolia.

$\beta$-thalassemia mutations are extremely heterogeneous [2-5]. It was reported that only 7 mutations comprise $67 \%$ of all $\beta$-thalassemia mutations [6,7]. Regional differences in the frequency of various mutations may offer clues regarding migration patterns and the ethnic background of a particular population $[3,6]$. It was previously reported that IVS1-110 (G-A), codon 8 (-AA), and IVS-2-1 (G>A) mutations were present in 28 of 51 patients with $\beta$-thalassemia in Şanlıurfa Province, Turkey [8]. The present study aimed to determine the prevalence of 22 mutations in 115 patients with $\beta$-thalassemia from Şanlıurfa Province, Turkey, and which occurred most frequently.

\section{Materials and Methods}

This study was conducted at Harran University, Education and Research Hospital, Pediatric Hematology outpatient clinic between March and May 2010. The study included 115 patients (60 male and 55 female) with a mean age of $7.3 \pm 4.6$ years (range: 1-17 years). The Harran University Education and Research Hospital Ethics Committee approved the study protocol, and written informed consent was obtained from all the patients' parents.

Blood samples were collected from the $\beta$-thalassemia patients into EDTA tubes and brought to the laboratory in a cold chain. The place and date of birth, and the name of each patient were recorded. Hematological analysis was performed the same day blood was collected using an automated cell counter (Cell Dyne 1700, Abbott Diagnostics). DNA was isolated via standard phenol-chloroform extraction and ethanol precipitation, and mutation analysis of the $\beta$-globin gene was performed using a commercially available reverse dot blot platform (Beta-Globin Strip Assay, Vienna Lab, Vienna, Austria). Mutations affecting gene transcription were $-101(\mathrm{C}>\mathrm{T}),-87(\mathrm{C}>\mathrm{G})$, and $-30(\mathrm{~T}>\mathrm{A})$, frame- 
shift types of premature termination (nonsense) mutation were codon 5 (-CD), codon 6 (-A), codon $6(\mathrm{G}>\mathrm{A}) \mathrm{HbC}$, codon $6(\mathrm{~A}>\mathrm{T}) \mathrm{HbS}$, codon 8 (-AA), codon $8 / 9(+\mathrm{G})$, and codon $44(-\mathrm{C})$, substitution types were codon $15(\mathrm{G}>\mathrm{A})$ and codon $39(\mathrm{C}>\mathrm{T})$, the exon processing type of RNA splicing mutation was codon $27(\mathrm{G}>\mathrm{T}) \mathrm{Hb}$ Knossos, the splice junction change in the 5' donor site was IVS-1-1 (G>A), splice consensus sequence changes in the 5' donor site were IVS-1-5 (G>A), IVS-1-6 (T >C), and IVS-2-1 $(\mathrm{G}>\mathrm{A})$, mutations within exons that affect processing internal IVS change were IVS-1-110 (G>A) and IVS-2-745 $(\mathrm{C}>\mathrm{G})$, the splice junction change in the 3' acceptor site was IVS-1-130 (G>C), the internal IVS change was IVS-1-116 (T>G), and the splice consensus sequence change in 3 ' acceptor site was IVS-2-848 (C>A) [9].

\section{Results}

In all, 22 mutations were investigated in 115 pediatric patients with $\beta$-thalassemia. Whereas 74 of patients were not related, 41 were brothers and/or sisters. In total, 16 different mutations in 208 alleles were identified, and IVS-1-110 (G-A) (29.1\%), IVS-1-1 $(\mathrm{G}>\mathrm{A})(13.9 \%)$, codon $(39(\mathrm{C}>\mathrm{T})(10.4 \%)$, and codon 8 (-AA) $(9.1 \%)$ accounted for $62.5 \%$ of all the $\beta$-thalassemia mutations (Table 1). IVS-1-110 (G>A) was the most frequent mutation type in the patients from Shanlıurfa Province, as in other geographic regions of Turkey. In all, $76 \%$ of the patients had consanguineous parents; $65 \%$ of these consanguineous marriages were between first cousins. $\beta$-thalassemia mutations were homozygous in $71.3 \%$ of the patients, heterozygous in $10.4 \%$, compound heterozygous in $4.8 \%$, and undetermined in $9.6 \%$.

In addition, the following 34 compound heterozygote mutant alleles were observed; IVS-1-1 (G>A)/ IVS-2-848 $(n=4)$, codon $39(\mathrm{C}>\mathrm{T}) /$ codon $8(-\mathrm{AA})$ $(\mathrm{n}=2)$, codon $6(-\mathrm{A}) / \mathrm{IVS}-1-5(\mathrm{G}>\mathrm{C})(\mathrm{n}=2)$, IVS-1-110 $(\mathrm{G}>\mathrm{A}) / \mathrm{IVS}-1-1 \quad(\mathrm{G}>\mathrm{A}) \quad(\mathrm{n}=2), \quad$ IVS-1-110 $\quad(\mathrm{G}>\mathrm{A}) /$ codon $8(-\mathrm{AA})(\mathrm{n}=1)$, IVS-1-110 $(\mathrm{G}>\mathrm{A}) /$ codon 39 $(\mathrm{C}>\mathrm{T}) \quad(\mathrm{n}=1), \quad$ IVS-1-110 $\quad(\mathrm{G}>\mathrm{A}) / \mathrm{IVS}-1-6 \quad(\mathrm{~T}>\mathrm{C})$ $(\mathrm{n}=1)$, IVS-1-110 $(\mathrm{G}>\mathrm{A}) / \mathrm{IVS}-1-5(\mathrm{G}>\mathrm{C})(\mathrm{n}=1)$, IVS1-110 $(\mathrm{G}>\mathrm{A}) /$ codon 8/9 $(+\mathrm{G})(\mathrm{n}=1)$, IVS-1-1 $(\mathrm{G}>\mathrm{A}) /$ codon $39(\mathrm{C}>\mathrm{T})(\mathrm{n}=1)$, and codon $8(-\mathrm{AA}) / \mathrm{IVS}-1-5$ $(\mathrm{G}>\mathrm{C})(\mathrm{n}=1)$ (Table 2). The following $\beta$-thalassemia mutations were not observed; $-101(\mathrm{C}>\mathrm{T}),-87$ $(\mathrm{C}>\mathrm{T}),-30(\mathrm{~T}>\mathrm{A})$, codon 15 (TTG $>\mathrm{TGA})$, codon 27 $(\mathrm{G}>\mathrm{T})$ Knossos, and VS-1-116 $(\mathrm{T}>\mathrm{G})$.
Table 1. The Frequency of 22 Different $\beta$-thalassemia Mutations in 230 Alleles

\begin{tabular}{|c|c|c|c|}
\hline Hom & nozygote (\%) & Heterozygote (\%) & Total (\%) \\
\hline IVS-1-110 (G>A) & $60(26.1)$ & $7(3.0)$ & $67(29.1)$ \\
\hline IVS-1-1 (G>A) & $22(9.6)$ & $10(4.3)$ & $32(13.9)$ \\
\hline codon $39(\mathrm{C}>\mathrm{T})$ & $18(7.8)$ & $6(2.6)$ & $24(10.4)$ \\
\hline codon 8 (-AA) & $16(7.0)$ & $5(2.2)$ & $21(9.1)$ \\
\hline IVS-1-5 (G>C) & $6(2.6)$ & $4(1.7)$ & $10(4.3)$ \\
\hline codon $5(-\mathrm{CD})$ & $8(3.5)$ & 0 & $8(3.5)$ \\
\hline codon $44(-\mathrm{C})$ & $8(3.5)$ & 0 & $8(3.5)$ \\
\hline IVS-1-130 $(\mathrm{G}>\mathrm{C})$ & $8(3.5)$ & 0 & $8(3.5)$ \\
\hline codon $8 / 9(+\mathrm{G})$ & $4(1.7)$ & $3(1.3)$ & $7(3.0)$ \\
\hline IVS-1-130 (G>C) & $6(2.6)$ & 0 & $6(2.6)$ \\
\hline IVS-1-6 (T>C) & 0 & $5(2.2)$ & $5(2.2)$ \\
\hline IVS-2-745 $(\mathrm{C}>\mathrm{G})$ & $4(1.7)$ & 0 & $4(1.7)$ \\
\hline IVS-2-848 (C>A) & 0 & $4(1.7)$ & $4(1.7)$ \\
\hline codon $6(-\mathrm{A})$ & 0 & $2(0.9)$ & $2(0.9)$ \\
\hline codon $6(\mathrm{G}>\mathrm{A}) \mathrm{HbC}$ & 0 & $1(0.4)$ & $1(0.4)$ \\
\hline codon $6(\mathrm{~A}>\mathrm{T}) \mathrm{HbS}$ & 0 & $1(0.4)$ & $1(0.4)$ \\
\hline$-110(\mathrm{C}>\mathrm{T})$ & 0 & 0 & 0 \\
\hline$-87(\mathrm{C}>\mathrm{T})$ & 0 & 0 & 0 \\
\hline$-30(\mathrm{~T}>\mathrm{A})$ & 0 & 0 & 0 \\
\hline codon 15 (TTG>TGA) & 0 & 0 & 0 \\
\hline codon $27(\mathrm{G}>\mathrm{T})$ Knossos & 0 & 0 & 0 \\
\hline IVS-1-116 (T>G) & 0 & 0 & 0 \\
\hline Undetermined & $22(9.6)$ & NA & $22(9.6)$ \\
\hline Total & 182 & 48 & 230 \\
\hline
\end{tabular}

Table 2. Compound Heterozygous - $\beta$-thalassemia Mutations in the 115 Pediatric Patients

\begin{tabular}{lcc}
\hline Mutation 1 & Mutation 2 & Frequency* \\
\hline IVS-1-1 (G>A) & IVS-2-848 & 4 \\
\hline codon 39 (C>T) & codon 8 (-AA) & 2 \\
codon 6 (-A) & IVS-1-5 (G>C) & 2 \\
IVS-1-110 (G>A) & IVS-1-1 (G>A) & 2 \\
IVS-1-110 (G>A) & codon 8 (-AA) & 1 \\
IVS-1-110 (G>A) & codon 39 (C>T) & 1 \\
IVS-1-110 (G>A) & IVS-1-6 (T>C) & 1 \\
IVS-1-110 (G>A) & IVS-1-5 (G>C) & 1 \\
IVS-1-110 (G>A) & codon 8/9 (+G) & 1 \\
IVS-1-1 (G>A) & codon 39 (C>T) & 1 \\
codon 8 (-AA) & IVS-1-5 $(G>C)$ & 1 \\
\hline
\end{tabular}

*Number of cases 


\section{Discussion}

$\beta$-thalassemia is a serious medical, social, and economic problem, both for affected families and the general population. To the best of our knowledge all published studies related to $\beta$-thalassemia mutations are concerned with thalassemia carrier status [3-5], and only 2 mutations in children with $\beta$-thalassemia [8]; as such, the present study is the first to examine 22 thalassemia mutations in 115 children with $\beta$-thalassemia from Şanlıurfa Province, Turkey.

Based on a comparison of the frequency of several mutations, IVS-1-110 (G-A) is the most common mutation in Syria, Macedonia, Greece, and Bulgaria, as in the present study (29\%), which is nearly half the rate previously reported for Turkey [2]. The IVS1-1 (G-A) mutation, which is highly prevalent in the Marmara and Aegean regions of Turkey, is among the 4 most common mutations in Mediterranean and Middle Eastern countries [8]; in the present study it was the $2^{\text {nd }}$ most common mutation (14\%). The order of frequency for other mutations, however, is different $[2,10,11]$. There are some differences between the frequency of mutations observed in Şanliurfa in the present study and that in the nearest provinces Gaziantep and Diyarbakir, e.g. the frequency of codon $39(\mathrm{C}>\mathrm{T})$ was $10.3 \%, 3.6 \%$, and $6.4 \%$, respectively [13].

It was reported that $-30(\mathrm{~T}>\mathrm{A})$ mutation, which is more common in eastern and southeastern Anatolia than other regions $[8,12]$, but its frequency is similar to Iran and Syria, was not identified in any mutant allele in Şanllurfa, a large city in southeastern Anatolia. IVS-2-1 (G>A) and codon 8 (-AA) are both $\beta$-thalassemia mutations associated with mild thalassemia, and are the 2 most common mutations in Azerbaijan [3]. Patients in the present study that had these mutations did not have mild thalassemias, and codon 8 (-AA) mutation was the $3^{\text {rd }}$ most common mutation we observed. IVS-1-130 (G>C) mutations are seen exclusively in patients originating from the city of Burdur in the Mediterranean Region of Turkey and have not been reported from any other country [2].

In the present study IVS-1-130 (G>C) mutations were noted in 6 homozygous alleles. The present findings illustrate the heterogeneity of $\beta$-thalassemia mutations in Şanlıurfa Province, as in other cities in
Turkey [2]. A broad range of mutations have been observed in Turkey, probably because of its location at the convergence of 3 continents and the subsequent influence of various ethnic groups [13]. The consanguineous marriage rate observed among the parents of the patients in the present study was $76 \%$, which is higher than previously reported [5], whereas the prevalence of compound heterozygous $\beta$-thalassemia mutations was lower (6\%).

Turkey has had a national hemoglobinopathy screening program since 2002, known as the Fight against Hereditary Blood Disease [14]. The program's guidelines were developed for the prevention and treatment of hemoglobinopathies. It is estimated that 150-200 infants will be born with $\beta$-thalassemia annually in Turkey [15]. Özdemir et al. reported that premarital screening and prenatal diagnosis are quite successful in preventing the birth of children with thalassemia major in Muğla, Turkey [16]. During such screening 131 at-risk couples were identified and those at risk of having children with hemoglobinopathy were referred for prenatal diagnosis. In all, 75 mothers underwent prenatal diagnosis and 21 were diagnosed with beta thalassemia major; in all the cases pregnancy was terminated in Muğla [16]. Since the start of premarital screening in Muğla, there have been no new $\beta$-thalassemia major births [16]. Conversely, a study on the efficacy of premarital screening in Hatay, Turkey, showed that only $17.5 \%$ of pregnant highrisk couples underwent prenatal diagnosis, despite receiving genetic counseling [17]. These results show that effectiveness of education in the hemoglobinopathy prevention program is inefficient in some province [15]. To the best of our knowledge no study related to the effect of Turkey's hemoglobinopathy screening program on the rate of children born with thalassemia has been published.

Controls of new thalassemic cases can be achieved in higher difficulties in Şanlıurfa Province, because of the presence of different ethnic groups that have large and young families, low socioeconomic and educational status, and as high as $65 \%$ close consanguineous and common-law marriages. Unfortunately, many at-risk couples still discover their risk only after giving birth to an affected child. In addition, at-risk couples find it very difficult to opt for abortion after learning that their fetus has $\beta$-thalassemia major or other severe diseases. In the 
present study mean age of the patients was $7.3 \pm 4.6$ years; in all, $53 \%$ of the patients were younger than 8 years and were born after Turkey's hemoglobinopathy screening program began.

Turkey's hemoglobinopathy screening program must take into account epidemiological and molecular data to set up the adequate strategy that sensitization and information about the disease, population screening and genetic counseling for carriers, and prenatal diagnosis for couples with affected children. In conclusion, we think that after having identified the most frequent mutations in $\beta$-thalassemia patients from Şanlıurfa Province, the frequency of premarital, preconception, and prenatal diagnosis will increase.

\section{Conflict of interest statement}

The authors of this paper have no conflicts of interest, including specific financial interests, relationships, and/or affiliations relevant to the subject matter or materials included.

\section{References}

1. Galanello R, Origa R. Beta-thalassemia. Orphanet J Rare Dis 2010:5:11. [CrossRef]

2. Altay C. The Frequency and Distribution Pattern of ss-Thalassemia Mutations in Turkey. Turk J Haematol 2002;19:309-15.

3. Aksoy M. Hemoglobinopathies in Turkey. Hemoglobin 1985;9:209-18. [CrossRef]

4. Arcasoy A, Cavdar AO. The incidence of thalassemia and abnormal hemoglobinopathies in Turkey. Acta Haematol 1971;45:313-7.

5. Altay C, Gürgey A. Distribution of hemoglobinopathies in Turkey. Report based on studies conducted at the Hacettepe Children's Hospital and the reviews of other studies. Turk J Pediatr 1986;28:219-29.
6. Altay Ç, Basak AN. Molecular basis and prenatal diagnosis of hemoglobinopathies in Turkey. Int J Pediatr Hematol Oncol 1995;2:283-90.

7. Basak AN, Özçelik H, Özer A, Tolun A, Aksoy M, Agaoglu L, Ridolfi F, Ulukutlu L, Akar N, Gürgey A, Kirdar B. The molecular basis of SS-thalassemia in Turkey. Hum Genet 1992;89:315-8. [CrossRef]

8. Dilmec F, Koc A, Akkafa F. Investigation of - SS globin gene mutations in patients with $\beta$-thalassemia in Sanlıurfa province of Turkey. Turkiye Klinikleri J Med Sci 2010;30:514-9.

9. Cunningham MJ, Sankaran VG, Nathan DG, Orkin SH. Classes of mutations that cause thalassemia. In: Orkin SH, Nathan DG, Ginsburg D, Look AT, Fisher DE, Lux SE eds. Hematology of Infancy and Childhood, 7th edition, Saunders, Elsevier Philadelphia, 2009:1023-33.

10. Kazazian HH Jr, Orkin SH, Markham AF, Chapman CR Youssoufian H, Waber PG. Quantitation of the close association between DNA haplotypes and specific ss-thalassaemia mutations in Mediterraneans. Nature 1984;310:152-4. [CrossRef]

11. Cao A, Galanello R. Beta-thalassemia. Genet Med 2010;12:61-76. [CrossRef]

12. Angastiniotis M, Modell B, Englezos P, Boulyjenkov V. Prevention and control of haemoglobinopathies. Bull World Health Organ 1995;73:375-86.

13. Pehlivan S, Okan V, Guler E, Yilmaz M, Sever T, Cankus C, Balat O, Pehlivan M. Thalassemia mutations in Gaziantep, Turkey. African Journal of Biotechnology 2010;9;1255-8.

14. Canatan D, Kose MR, Ustundag M, Haznedaroglu D, Ozbas S. Hemoglobinopathy control program in Turkey. Community Genet 2006;9:124-6. [CrossRef]

15. Sarper N, Şenkal V, Güray F, Şahin Ö, Bayram J. Premarital hemoglobinopathy screening in Kocaeli, Turkey: a crowded industrial center on the north coast of Marmara Sea. Turk J Haematol 2009;26:62-6.

16. Özdemir S, Timur IH, Gencer İ, Akar N. Premarital screening in Muğla region of Turkey. Turk $\mathrm{J}$ Hematol 2009;26:214-5.

17. Gali E, Polat G, Doğdu, G, Akgöl M, Parlar M, Yüregir G. Hatay ilinde evlilik öncesi hemoglobinopati sonuçlarının değerlendirilmesi. Mersin Üniversitesi Tıp Fakültesi dergisi 2001;3:305-10. 